\title{
THE IMPACT OF EVANGELICAL REVIVALS ON GLOBAL MISSION: THE CASE Of North AMERICAN EVANGELICALS IN BRAZIL IN THE NINETEENTH AND TWENTIETH CENTURIES
}

Author:

Edward L. Smither ${ }^{1,2}$

\section{Affiliations:}

${ }^{1}$ Church History and

Intercultural Studies,

Liberty University,

Lynchburg, Virginina, USA

${ }^{2}$ Department of Missiology, University of Pretoria,

Pretoria, South Africa

Correspondence to:

Edward Smither

email:

elsmither@liberty.edu

Postal address:

1971 University Boulevard,

Lynchburg, VA 24502, USA

\section{Keywords:}

Brazil; Great Awakening; majority world missions; nineteenth century; revivals

\section{Dates:}

Received: 04 Nov. 2009 Accepted: 28 June 2010

Published: 28 Sept. 2010

How to cite this article: Smither, E.L., 2010, ' The impact of evangelical revivals on global mission: The case of North American evangelicals in Brazil in the nineteenth and twentieth centuries', Verbum et Ecclesia 31(1), Art. \#340, 8 pages. DOI:10.4102/ve.v31i1.340

This article is available at: http://www.ve.org.za

(c) 2010. The Authors. Licensee: OpenJournals Publishing. This work is licensed under the Creative Commons Attribution License.

\section{ABSTRACT}

The aim of the current article is to show that an important element behind the establishment of evangelical missions to Brazil - particularly during the pioneering stages - was evangelical revival, especially that which occurred in North America during the nineteenth century. Following a brief introduction to the general relationship between eighteenth- and nineteenthcentury revivals and evangelical missions, I shall endeavour to support historically the commonly accepted, yet often unsubstantiated, correlation between such movements of revival and mission. Firstly, I will show the significant paradigm shift in missional thinking, which took place in the nineteenth century, as North American evangelicals began to regard Roman Catholic countries in Latin America as mission fields. Secondly, I shall argue that the influence of nineteenth-century revivalist evangelicalism (particularly that sourced in North America) on missions to Brazil and Latin America can best be observed in the Brazilian evangelical identity that emerged in the twentieth century, which has, in turn, propelled the Brazilian evangelical church into its own significant involvement in global missions (Noll 2009:10).

\section{INTRODUCTION}

When representatives of the American Bible Society reached Brazil in around 1816, it marked not only the beginning of Bible distribution in both the country and in Latin America as a whole, but it also signified the beginning of a significant wave of evangelical Protestant missions which was spread throughout the region by Methodists, Presbyterians, Baptists and other evangelical groups. Such groups were followed by Pentecostal groups in the early twentieth century. By 1890, there were just 143000 Brazilian evangelicals; however, today that number has swelled to over 30 million. While Brazil is still considered one of the largest Roman Catholic countries in the world, it is quickly becoming one of the fastest growing evangelical ones as well, with some projections holding that Brazil will be $50 \%$ evangelical by 2020 (Prado n.d., 2002:52).

The aim of the current article is to show that an important element behind the establishment of evangelical missions to Brazil - particularly during the pioneering stages - was evangelical revival, especially that which occurred in North America during the nineteenth century. Following a brief introduction to the general relationship between eighteenth- and nineteenth-century revivals and evangelical missions, I shall endeavour to support historically the commonly accepted, yet often unsubstantiated, correlation between such movements of revival and mission. Firstly, I will show the significant paradigm shift in missional thinking, which took place in the nineteenth century, as North American evangelicals began to regard Roman Catholic countries in Latin America as mission fields. Secondly, I shall argue that the influence of nineteenth-century revivalist evangelicalism (particularly that sourced in North America) on missions to Brazil and Latin America can best be observed in the Brazilian evangelical identity that emerged in the twentieth century, which has, in turn, propelled the Brazilian evangelical church into its own significant involvement in global missions (Noll 2009:10).

\section{EVANGELICAL REVIVALS AND MISSIONS}

Bevans and Schroeder refer, in particular, to three periods of pietistic revivals which had missional implications. The first was the Great Awakening, which occurred in Europe and North America in the early eighteenth century (Bevans \& Schroeder 2004:209-210). Though a deliberate foreign missions movement did not directly result from such an awakening, Ahlstrom argues that it birthed a missionary spirit, which was most easily observable in the evangelical work carried out among Native Americans (Ahlstrom 2004:289; cf. Bosch 1990:278; Kidd 2008:139). Besides being a key preacher during the Great Awakening, Jonathan Edwards was instrumental in facilitating prayer for global mission, while casting a general vision for such mission through the publication of his famous Life of David Brainerd (George T. 2008:48; Hall 2009:21-24). Bevans and Schroeder (2004:209-210) state that in the second period - the Methodist revival - Wesley and his followers integrated evangelical preaching with social action, and successfully blurred the lines between domestic and global mission.

It was not until the third period of revival - termed the Second Great Awakening which occurred in North America during the first third of the nineteenth century - that the connection between domestic and foreign mission work became apparent. Chaney (1976:174) and Bosch (1990:279) assert that by 1817, participation in missions had become a matter of conviction for evangelicals in North America. While acknowledging that the origins of traditional evangelism hark back to the eighteenth-century evangelical awakening in Britain and parts of the continent', Guillermo Cook argues that 'the Great Awakening in the nineteenth century propelled US missionaries to Latin America' (Cook 1994c:44). Willems affirms that, after 1850, an evangelical missions movement characterised by the values of 
North American revivalism could be observed to be emerging in the Brazilian context (Willems 1967:4-6). Finally, Bonino (1995) offers the following helpful summary:

The initiators [of] Latin American evangelicalism were missionaries - largely North American or British . . . who arrived in Latin America from the 1840 decade onward. It is remarkable to note that, despite their confessional diversity (mostly Methodists, Presbyterians, and Baptists) and origin (North American and British), all shared the same theological horizon, which can be characterized as evangelical.

(Bonino 1995:27)

In the light of Bonino's comments, it is worthwhile to provide a brief answer to the following question: What values and characteristics of British and North American evangelicalism were championed during such revivals, which spread to Brazil and the rest of Latin America? Though articulated within a British context, David Bebbington's famous quadrilateral seems to offer the best description of evangelicals - regardless of their nationality or denomination - in the eighteenth and nineteenth centuries. Briefly, Bebbington's paradigm includes the following categories: Biblicism, meaning the commitment to the authority of the Scriptures; Crucicentrism, which consisted of an emphasis on Christ's atoning work on the Cross; Conversionism, which consisted of the conviction that one must be converted through saving faith in Christ's atoning work; and Activism, the resulting commitment to evangelism, missions, and Christian service. Bebbington's (1989) categories, which were developed in his classic work Evangelicalism in modern Britain, have recently elicited fresh interaction from Haykin and Stewart (2008) in their The advent of evangelicalism. The categories continue to offer a helpful reference point for defining evangelicalism on a global scale (cf. Noll 2004:36).

\section{EVANGELICAL MISSIONS AND ROMAN CATHOLICISM}

One clear outcome of the nineteenth century evangelical awakenings on missions was that they sparked a seismic paradigm shift in missionary thinking. The result of such a paradigm shift was that the Roman Catholic countries, including Brazil and its neighbours in Latin America, came to be considered legitimate evangelical Protestant mission fields. Indeed, the relatively late start of evangelical missions in Latin America can best be explained by the fact that the majority of mainline Protestant denominations worldwide - especially the Anglican faith - did not regard Roman Catholics as unbelievers (Gonzalez 2007:208; Saracco 2000:359). Even the planners of the 1910 Edinburgh consultation on world evangelisation held such a view, as they did not invite Protestant mission groups working in Latin America to attend the conference (Escobar 2002:24; Scott 2009:375).

Such a change in thought came on the heels of the Second Great Awakening, which, among other things, insisted on the need for personal conversion - a value that will be discussed in more detail shortly. Such an evangelical value, especially when applied to the spiritual state of Latin America, was nurtured and advanced within the Student Volunteer Movement. In some respects, the Movement had strong parallels with the famous Haystack prayer meeting, which was held at Williams College in 1806. The meeting in question gave rise to a revival, which led to the formation of the American Board of Commissioners for Foreign Missions in 1810, and to that of the American Bible Society in 1816 (Ahlstrom 2004:422-424; George 2002:104). Although the American Board was primarily focused on Asia during its early stages, there was still great interest in South America. As noted, the American Bible Society began working in Brazil during the first years of its existence.

The Student Volunteer Movement was birthed in 1886 in Mt. Herman, Massachusetts, following a four-week long Young
Men's Christian Association collegiate camp led by Dwight L. Moody. Though Moody's focus was on North American missions, and the camp did not have an intentional global focus, the revivalist atmosphere, nevertheless, sparked a vision for global missions, for which 100 students immediately volunteered. Officially constituted in 1888, the Student Volunteer Movement's watchword was 'evangelization of the world in this generation', and, according to Michael Parker, between 1886 and 1920, over 8700 individuals followed through on the call, entering overseas missionary service (Parker 1998:2-21; Robert 1986:146)

From its very first year, the Movement's leadership was concerned with evangelising Roman Catholic Latin America. In 1886, A.T. Pierson, referring to Catholic countries in general, declared that the priest ridden masses are weary of their thralldom' (cited in Parker 1998:69). By far the most influential voice from the Student Volunteer Movement on the Latin American situation was that of Robert Speer, who later authored South American problems (1912). Despite the Roman Catholic presence in Brazil and Latin America, Speer cited the 'problems of alcoholism, sanitation, disease ... high mortality rate ... [and] illiteracy' (cited in Parker 1998:116). He further stated:

No land can be conceded to have a satisfactory religion where there moral conditions are as they have been shown to be in South America. If it can be proved that the conditions of any European or North American land are as they are in South America, then it will be proved also that that land needs a religious reformation. (cited in Escobar 2002:25; cf. Cook 1994c:44)

While discouraging direct polemical attacks on the Catholic Church, Speer initially viewed evangelical efforts in South America as a means of purifying the Roman Catholic Church (Escobar 2002:60). However, later he concluded that the only hope of reformation would seem to be separation from Rome and the formation of national churches' (eds. Speer, Inman \& Sanders 1925: 2, 398).

Speer and Pierson's (1925) conclusions on the matter resulted in concrete action, in connection with which a consultation met in New York in 1913 - just three years after the Edinburgh meeting had taken place - to consider the viability of undertaking evangelical mission work in Latin America. In 1916, a conference was held in Panama to discuss further strategies to be adopted for Latin America, with subsequent conferences with similar goals being held in Montevideo in 1925 and in Havana in 1929 Speer and others helped to form the Committee of Cooperation for Latin America, while a similar group was started with the intention of focusing specifically on Brazil. Finally, in 1930, a federation of evangelical churches for Latin America was founded (Latourette 1937-1945: 7, 172-173).

In the early twentieth century, other evangelical leaders affirmed Speer's view on the need to evangelise South America. At the 1916 congress in Panama, Bishop William Cabell Brown communicated compassion for Roman Catholics, as well as a conviction for biblical truth:

Suppose I were talking to a Roman Catholic. You know how kindly and considerate I would be. I would not desire to offend him or drive him away. I should rather try to speak the truth in love, and if possible, lead him to the full knowledge of the truth.

(cited in eds. Speer et al. 1925:2.398)

Responding to the criticisms of those who opposed the evangelisation of Catholic countries, John McKay defended the work of evangelical missionaries in the region:

Sometimes those who are interested in Christian service in South America are apt to be regarded as religious buccaneers devoting their lives to ecclesiastical piracy, but that is far from being the case. The great majority of men to whom we go will have nothing to do with religion. They took up this attitude because religion and morality had been divorced throughout the whole history of religious life in South America.

(cited in Escobar 2002:26) 
In 1916, Brazilian Presbyterian Pastor Erasmo Braga predicted that evangelical revival would actually mark the end of 'paganism' in the Latin American Catholic context (Escobar 2002:27; cf. Latourette 1937-1945: 5, 109). Such a concern for evangelising Catholics, which seems to have had its roots in the North American awakenings, has continued to be valued by Brazilian and Latin American evangelicals up until now. More recently, Báez-Camargo remarked that the 'self designated "Christian world" was also a mission field itself' because

the kingdom of God cannot be defined in terms of mere territorial accretion, but that the whole of life everywhere must be brought under the Lordship of Jesus Christ.

(cited in Escobar 2002:26)

\section{BRAZIL'S EVANGELICAL IDENTITY}

Although a number of scholars confidently assert that evangelical mission work in Latin America and Brazil emerged as an outcome of the Second Great Awakening in North America in the mid-nineteenth century, the connection of such work to such an Awakening is, at best, subtle. That is, the revivalist church leaders did not declare that global mission was the logical next step in the awakenings. Also, those missionaries who worked in Brazil in the early to mid-nineteenth century did not claim that awakenings in their home country had driven them to the mission field. Though international students at the Mt. Hermon Conference in 1886 addressed a Macedonian call of sorts to the assembled delegates, such a move was certainly not Moody's intention when organising the summer retreat. Bosch, offering a theological interpretation of the increased emphasis on missions, asserts that, in such an atmosphere of revival, it was the constraining love of Christ which began to grip North American believers:

There was among the Christians touched by the Awakening, a tremendous sense of gratitude for what they had received and an urgent desire to share with others, both at home and abroad, the blessings so freely shed upon them.

(Bosch 1990:286)

To be sure, it does not seem to be a coincidence that the three mainline denominations which were most affected by the Second Great Awakening - the Methodists, the Presbyterians, and the Baptists - were also the first to initiate mission work in Brazil.

In a rather critical fashion, Rubem Alves has asserted that the 'Pietism and revivalism brought to Brazil by the early missionaries ... has now been taken over and made an integral part of modern Brazilian Protestantism' (cited in eds. Penyak \& Petry 2006:230; cf. Martin 1993:273-274). In the light of such claims and in the light of the lack of clear causality between the Second Great Awakening and the advent of evangelical missions to Brazil, perhaps the best way to show the influence of North American revivals on evangelical missions in Brazil is to examine the identity of Brazilian evangelicalism and to observe the values shared by the two movements concerned. Six areas are particularly apparent, and will now be explored: a high regard for the Scriptures; a call to genuine conversion; a visible faith; a missionary zeal; the priesthood of the believer; and a free church tendency.

\section{A high regard for the Scriptures}

The first evangelical and revivalist value observed in Brazilian evangelicalism is the primacy of the Scriptures in the believer's life and in the community of faith. Alves critically refers to such primacy as a 'type of Protestantism, which has given a central place to the reading and study of the Bible' (cited in eds. Penyak \& Petry 2006:230). Similarly, Mendonça cites the 'literalist biblicism' of Brazilian evangelicals, which, he argues, came from the North American missionaries (Mendonça 1996:385).
Such a regard for the Scriptures - which is a core value of the Protestant Reformation, as well as of the pietistic revivals - is what motivated the evangelical pioneers in Brazil to translate and distribute the Bible. Escobar (2002) writes:

This was a pillar of Protestant missiology, which considered Bible translation and distribution as the beginning of missionary activity that would allow for the communication of the faith and the development of indigenous churches.

(Escobar 2002:69; cf. Robert 2000:56)

As noted, the work of evangelical missions in Brazil was launched before 1820 through the work of Bible Society 'colporteurs', while other evangelists, such as Robert Reid Kalley, incorporated distribution into their overall mission strategy (Winfried Every-Clayton 2002:325; cf. Cook 1994c:45; Escobar 1994:35). Bible distribution continued to be a valued strategy throughout the twentieth century, and is still regarded as important, even in the present day (ed. Douglas 1974:1344). Commenting on its impact in the early twentieth century, Braga (1932) wrote:

There are many cases illustrating the effect of reading the Bible on individual lives as well as on the community life. This has led to definite conversions, and has been instrumental in raising up many notable workers.

(Braga \& Grubb 1932:72; cf. Latourette 1937-1945: 2, 215-238)

Bonino (1995) adds that, as evangelical mission work engaged the Latin American context, a polemic against Roman Catholicism developed, which also encouraged an emphasis on the Scriptures. He writes:

It was necessary to furnish new converts with knowledge and arguments for this conflict. That need led to a great emphasis on study of the Bible and of the basic doctrines of Protestantism.

(Bonino 1995:31)

While Brazilian Pentecostalism has experienced unprecedented growth in the twentieth century, Stoll and others have criticised the evangelicals involved with such Pentecostalism for possessing only a superficial understanding of biblical Christianity (Stoll 1991:173; cf. Cook 1994b:276). However, Mariz counters that, whereas many Brazilians had initially been attracted to the Pentecostal church because of their intense spiritual experience, it was the knowledge which they gained from a literal reading of the Scriptures which kept them in the church (Mariz 1994:77-78). Such Christians are certainly among those referred to by Philip Jenkins in his recent work, The new faces of Christianity, which is appropriately subtitled Believing the Bible in the global South (2006).

Brazilian evangelicalism has certainly embraced the pietistic value of a high regard for the Scriptures; however, evangelical missionaries, especially in the pioneering stages, largely appealed to the literate population and failed to engage with the large number of Brazilians who were either illiterate or only functionally literate. In 1890, Hugh Tucker estimated that only $15 \%$ of the Brazilian population could read, whereas in 1930 Braga acknowledged that only $25 \%$ of the population were literate (Tucker 1902:72; cf. Braga \& Grubb 1932:72). At the 1925 Montevideo Congress, W.A. Waddell criticised evangelical missions in Latin America in general for disproportionately focusing on efforts to evangelize the educated classes (eds. Speer et al. 1925:1.138). In contrast, the distribution of Bibles and other religious literature became increasingly more relevant through the course of the twentieth century, with the level of literacy currently standing at $88 \%$ among Brazilians aged fifteen and above (Central Intelligence Agency World Factbook [s.d.]; cf. Read \& Ineson 1973:1).

\section{A call to genuine conversion}

A second observable revivalist influence on Brazilian evangelicalism is the necessity for conversion. René Padilla (1994) asserts: 
In this respect, the evangelical churches in Latin America prove to be, in general, heirs of the great evangelical revivals of the eighteenth and nineteenth centuries, with their emphasis on the doctrine and experience of salvation by the grace of God, through faith in Jesus Christ.

(Padilla 1994:90; cf. Bevans \& Shroeder 2004:230; Bonino 1995:28; Escobar 2003:103-104; Willems 1967:6)

The emphasis on conversion can certainly be traced back to the pre-Great Awakening ministry of Samuel Torrey, who insisted that spiritual reformation begins with saving faith (Kidd 2008:131-132). We are also reminded that Jonathan Edwards was dismissed from his pastorate at Northampton, Massachusetts, for refusing to admit the unconverted to the Lord's Table. Ironically, Edwards spent his final years serving as a missionary to Native Americans (Noll 1992:104). Finally, the preaching of Timothy Dwight, James McGready, and Dwight L. Moody, among others, was also undergirded by such an evangelical value (Hankins 2004:6-9).

Just as evangelical missionaries to Latin America were committed to the doctrine of conversion, Cook points out that they were also motivated by a sincere concern to rescue souls from a literal hell (Cook 1994c:45). Convinced that the primary task of every Christian was to witness to others and seek their conversion', such missionaries held that public preaching and personal witness should be the key forms of evangelism (Gonzalez 2007:203-204; cf. Arnold 2006:125). It is interesting to note that some Pentecostal evangelistic meetings even resembled the Methodist, Wesleyan, and Holiness camp meetings of nineteenth-century North America, which included 'godly hysteria, holy dancing, and laughter' (Martin 1993:28, 163-164; cf. Bonino 1995:32-33; Hankins 2004:7)

Finally, the evangelical emphasis on conversion in the Brazilian context in the nineteenth and twentieth century implied the need for a personal and individual conversion (Escobar 2002:41 cf. Horner 1965:26; Mariz 1994:76-77; Mendonça 1996:383-385). Such a Reformation and pietistic value was, of course, quite distinct from the previous Roman Catholic model of spreading Christendom throughout Brazil. Jenkins points out that the anti-evangelical publication Os demônios descem do Norte ("The demons come down from the North'), only one such publication of the numerous others brought out by the Brazilian Catholic Church, indicates that the Roman Church viewed evangelicals from North America as invading their domain (Jenkins 2007:179).

Brazilian and Latin American Protestants have also expressed concern about, and criticism of, the doctrine of individual conversion. Cook argues that North Americans, influenced by the Enlightenment values of individualism, subconsciously sought to impose such a doctrine on the Brazilian culture, which was more communal in nature (Cook 1994c:45). Mendonça, in particular, has accused American Presbyterians of being too 'heavenly minded' and of not caring enough for the social needs of Brazilians (cited in Arnold 2006:129-130). Finally, Escobar, a leading evangelical theologian, has expressed concern that a focus on individual conversion has stifled a proper ecclesiology, in which the community of faith is taken as serving as an agent of transformation in society (Escobar 2002:43; cf. Escobar 1994:28). In response to such a focus, Brazilian evangelicals in the twentieth century forged their own evangelical identity, in part by celebrating conversion on the family and community level, rather than on the individual level. In particular, Orlando Costas influenced Latin American Mission's Evangelismin-Depth programme to become more contextualised, with evangelism being carried out as a form of outreach to the community, paying careful attention to human needs within such a context (Smith 1983:202-210).

\section{A visible faith}

A third revivalist value also evident in Brazilian evangelicalism is the emphasis on the visible practice of faith (Escobar 2002:102). According to Hoornaert (1992:193-194), it seems that a devotional and pietistic form of Christianity, which was first introduced by Jesuit missionaries, had existed among some Brazilian Catholics prior to the arrival of the evangelical missionaries. As a result, evangelical missions from North America seemed to stoke such a spirit among the relevant Catholic segment, the members of which were also anti-clerical and anti-hierarchical. Alves (cited in eds. Penyak \& Petry 2006) adds that many observers of Brazilian evangelicalism are

impressed by the extraordinary vitality of the simple piety of the average Christian. Here are people for whom the experience of a personal relationship with Jesus Christ is the very center of life, people who read their Bibles and pray daily.

(Alves cited in eds. Penyak \& Petry 2006:230)

Such a visible faith was immediately discernible in what Brazilian evangelicals avoided - smoking, dancing, sexual immorality, and drinking alcohol, among other such 'vices'. In fact, a key strategy discussed at the Montevideo Congress in 1925 was the implementation of a temperance movement in Brazil and Latin America (eds. Speer et al. 1925:1.406, 2.10). Gonzalez asserts that North American evangelical missionaries preached a Gospel that included temperance convictions consistent with those of the American Society for the Promotion of Temperance, which had been founded in 1826 during the Second Great Awakening (Gonzalez 2007:207; cf. Ahlstrom 2004:425-427). The other noted areas of abstinence find parallels in nineteenth-century North American Baptist meetings, which opposed drinking, sexual sin, and dishonest business dealings (Hankins 2004:15). As the evangelical message spread in Brazil, a conflict arose between the North American missionaries and the immigrant churches, which had been established by expatriates from Germany, Italy, England, the United States, and other countries during the waves of immigration which had occurred between 1820 and 1915. As the immigrant churches had no problem with many of the forbidden practices, Mendonça distinguishes between a 'Protestantism of mission' and a 'Protestantism of immigration' in the Brazilian context (Mendonça 1996:381-382).

In addition to those practices which were avoided by the Brazilian evangelicals, such a visible faith could also be observed as resulting in the moral transformation of many of the inhabitants of the country. Abstinence from sexual activity outside of marriage - a counter-cultural tendency, to be sure - led to increased sexual purity for both singles and married couples alike, and brought greater stability to families, which, in turn, served to strengthen the evangelical congregations (Willems 1967:45-54, 169-173; cf. Chestnut 1997:59-65; Cook 1994a:xi; Robert 2000:56). Finally, moral transformation could also be observed in the intellectual and economic improvement of Brazilian believers (Comblin 1994:219; Mariz 1994:78-79).

Such a visible and transformative faith was supported by the belief in a Gospel that was holistic and integrative. That is, while nineteenth-century North American missionaries - influenced by evangelical revival - preached a verbal Gospel, which invited converts to believe in the atoning work of Christ for the forgiveness of sin, they also gave much attention to real human needs. As noted, such values had already been observed in the ministry of John Wesley and the Methodist revivals. One of the outcomes of the eighteenth-century Great Awakening in New England was new initiatives in education and higher learning: Baptists founded Brown; Presbyterians started Princeton; the Dutch Reformed founded Rutgers; and the Congregationalists began Dartmouth (Noll 1992:100-101; cf. Ahlstrom 2004:289290; Spickard \& Cragg 1994:265-266). Ahlstrom adds that one fruit of the Second Great Awakening was increased work among the poor and the handicapped (Ahlstrom 2004:427-428).

Describing the integrative approach of nineteenth-century evangelicals to Brazil and Latin America, Bonino (1995) writes:

Religious awakening and social reformation (revival and reform) were seen as intimately related; the 1850 evangelists took upon themselves, along with the moral improvement of society, the cause of the abolition of slavery and the struggle against poverty.

(Bonino 1995:29) 
Whereas many such as Kalley were vocal in their opposition to slavery and others devoted their energy to the plight of the poor, one clear evangelical contribution was the development of schools - both theological and liberal arts institutions - and hospitals (Latourette 1937-1945: 5, 123; cf. Arnold 2006:130-133; George 2006:94; Robert 2000:56). At the Montevideo Congress in 1925, a mission strategy for Brazil's indigenous peoples was proposed, which addressed educational, medical, and economic needs (eds. Speer et al. 1925:1.190-192). Although evangelicals have continued to be criticised by liberal Protestants for not caring enough about social needs (Bonino 1995:144; cf. Arnold 2006:129-130; Prado 2005:51-52), Revd A.G. Tallon in 1925 seems to have expressed well the prevailing nineteenth- and twentieth-century evangelical missionary conviction in Brazil:

It is a mistake to contrast evangelism with social service. Any social work that is worthwhile grows out of spiritual convictions. A minister needs to be zealous in laying right foundations for his people ... twenty-eight years experience in preaching the gospel emphasizing Jesus Christ, holiness of life and the embodiment of the Master's teachings and character has not gone for naught. It has developed a people ready to do their share in community service.

(cited in eds. Speer et al. 1925:1.378)

Such an emphasis on an integrated Gospel has certainly become one of the most vital aspects of the Brazilian evangelical identity. Referring to the contemporary church in Brazil and Latin America, Rey asserts:

It is now normal to find next to a church, regardless of its size, a health center, a school, a soup kitchen, etc. The majority of the churches have understood that they have an integral mission and that evangelization goes hand in hand with social responsibility. (cited in eds. Penyak \& Petry 2006:360)

Whereas such a value can be observed in the practice of churches in general, some of the most compelling missiology on the relationship of the Scriptures with its proclamation and social engagement continues to come from such men as Samuel Escobar, René Padilla, Guillermo Cook, and Valdir Steuernegal - all members of the Latin American Theological Fraternity - and their emphasis on the 'whole Gospel' (termed the evangelizacion integral in Spanish, and the missão integral in Portuguese).

\section{A missionary zeal}

A fourth area of continuity between North American evangelical awakenings and Brazilian evangelicalism is an emphasis on missions. Despite the cultural baggage of the Manifest Destiny, which was introduced by many wellmeaning nineteenth-century missionaries, such hegemony did not impede the Brazilian church from cultivating its own form of missionary zeal. In 1923, an expatriate mission leader travelling throughout the country remarked that 'great self-supporting churches are found in the cities, with large memberships, and doing real missionary work in their own districts' (Braga \& Grubb 1932:83). Braga adds that, in the early twentieth century, evangelical churches from across denominational lines collaborated in evangelistic outreaches, distribution of the Scriptures, and university student and women's ministry. During the 1930s, Brazilians strove to reach out to the Japanese, Muslim, and Jewish immigrant populations in the country (Braga \& Grubb 1932:88-89, 111-113). Around 1920, Brazilian Baptist missionaries J.J. Oliveira and Antonio Mauricio were sent to minister in Portugal, where they were later joined by Presbyterians João Marques de Mota and Erasmo Braga (Anderson 2005:150-155; Ekström 1998:7-8; Salinas 2008:134). Such missionary conviction continued to manifest itself in increased transcultural efforts both inside Brazil and around the world in the latter part of the twentieth century. In 2009, with nearly 5000 transcultural workers serving on every continent, the Brazilian evangelical church surpassed its British and Canadian counterparts in the number of missionaries sent to other lands (Ekström 2009:372; Noll 2009:10).
Such a missional emphasis is perhaps best captured by those outside Brazilian evangelical circles. Alves writes, 'The church is constantly engaged in evangelistic and mission work' (cited in eds. Penyak \& Petry 2006:231). José Comblin, a Belgian Catholic missionary in the north-east of Brazil, made the following remark about Pentecostals in the region: 'This may be the most decisive factor; every believer is a missionary' (Comblin 1994:219). Finally, Bonino, summarising Latin American evangelical theology in general, asserted that 'mission' was the 'material principle' of the entire movement (Bonino 1995:ix-x; cf. Escobar 2002:102, 134).

\section{Priesthood of the believer}

Related to their missionary zeal, Brazilian evangelicals have also noticeably exhibited the Reformation, pietistic, and revivalist value of the priesthood of the believer. Such a concept can be understood in at least three different ways. Firstly, regarding the Scriptures, Luther's notion of perspicuity - the idea that even the simplest person could understand the Scriptures and communicate them to others - contributed to the rise of Brazilian evangelicalism (Escobar 2002:73-74; cf. Escobar 2003:131-132). Bosch notes that such biblical conviction, especially among those with premillenial eschatological views, was an energising factor in nineteenth-century missions, including those which were intent on evangelising the Brazilian population (Bosch 1990:316). Such an evangelical value was certainly also behind the American and British Bible Societies' decision to print and distribute Bibles without study notes or commentaries. Such an outlook was distinct from the Catholic Church's strategy of using notes to teach literate parishioners about Catholic theology, which seemed to diminish the role of the biblical text itself (Gonzalez 2007:218).

A second way in which the priesthood of the believer has been observed in Brazilian evangelicalism is in its emphasis on volunteerism. Although such an ideal was largely absent in Christian history from the time of Constantine until the Anabaptist Reform (Stark 2001:107), volunteers not only led the European and North American awakenings, but the revivals also seemed to produce more labourers. While the First Great Awakening effectively empowered lay leaders and preachers, one outcome of the Second Great Awakening was the prolific formation of voluntary missionary societies (Noll 1992:112, 169; cf. Ahlstrom 2004:422-424; Bosch 1990:280, 332). Summarising such a tendency within the context of evangelical awakenings, Bevans and Schroeder (2004) conclude:

Instead of waiting for a signal from an official church, individual Christians, often across denominational affiliations, joined societies to commit themselves to the task of world mission. Lay people as well as clergy were involved in these associations.

(Bevans \& Schroeder 2004:210).

Comblin's observation that, in north-east Brazil, 'every believer is a missionary' suggests a strong grassroots and volunteering tendency among Brazilian churches as well (Comblin 1994:219; cf. Robert 2000:56). The holding of such a value was certainly encouraged by Kenneth Strachan's Evangelism-inDepth strategy, beginning in 1959, which emphasised 'total mobilization for total evangelization', as well as in the strategy of the 1969 Latin American Congress on Evangelisation (CLADE I), which stressed mobilising the whole church for the evangelistic task' (Saracco 2000:361; cf. eds. Penyak \& Petry 2006:360; Willems 1967:6). Remarking that such a tendency is second nature to most Brazilians, George writes: 'Many Protestant churches in Brazil feel no need to have an evangelism committee because members of the congregation actively practice evangelism with relatives, neighbours, friends, and strangers' (George 2002:105). Summarising the connection between volunteerism observed in the evangelical awakenings and in Brazil and Latin America, Padilla (1994) asserts:

the lay ministry is one of the characteristics that show the Protestantism which has taken root in Latin America is related to the revivalists Protestantism of the eighteenth century.

(Padilla 1994:89; cf. Martin 1993:273) 
A final way in which Brazilian evangelicalism has exhibited such conviction has been in the setting apart of the indigenous lay and full-time vocational ministers from an early stage Despite the difficulties which have, at times, been experienced in the relationships between the North American missionaries and Brazilian believers, especially in relation to the paternalism of some of the former, efforts to place Brazilians in positions of leadership have been evident (George 2006:136; cf. eds. Speer et al. 1925:2.257-259). Braga affirms, 'From the very beginning, nationals were carefully selected and made fully responsible for the work entrusted to them' (Braga \& Grubb 1932:117).

While such empowerment has occurred on an individual level, the larger mainline denominations - the Presbyterians, the Methodists, and the Baptists in particular - also came under Brazilian leadership at a fairly early stage. Latourette asserts that they 'became ecclesiastically independent of foreign control', which 'tended to reduce their foreign character' (Latourette 1937-1945: 5, 123; cf. Stoll 1991:109). The main Pentecostal denominations were, from the outset, largely Brazilian in identity. The Assemblies of God, Brazil's largest evangelical denomination, was founded by missionaries from North America, who later affiliated with the international denomination of the church (Gonzalez 2007:281; cf. Cook 1994c:46; Sepúlveda 1994:68). In a study of Pentecostal churches in Rio de Janeiro in 1992, Freston (2004:232) found that 37 of the 52 denominations were of Brazilian origin, with nearly every church being led by a national pastor.

Both the official denominations and the independent churches of the Pentecostal movement have been at the forefront of setting apart spiritual leaders, especially lay leaders, including those from poor backgrounds and with little formal education. Such a tendency reflects Pentecostalism's general affinity with the poor, with its simultaneous emphasis on the Holy Spirit's anointing of spiritual leaders, rather than on the need for a minister to undergo formal training. According to Kane (1982:149; cf. Chestnut 1997:30-31, 135), in 1980, whereas the Assemblies of God had twenty official missionaries in Brazil, they also had 29000 licensed ministers and another 27000 lay workers who served in the church. In addition, in its early years, the Congregacão Cristã no Brasil (the Christian Congregation of Brazil) had no ordained or full-time vocational ministers. Hence, these larger Pentecostal denominations have, in the past, largely relied upon bivocational and lay ministers (Gonzalez 2007:281; cf. Berg \& Pretiz 1994:62; Willems 1967:145). Finally, among the rapidly expanding independent Pentecostal communities in north-east Brazil, Comblin observes that 'pastors are numerous and multiply amazingly' (Comblin 1994:219-220).

\section{Free church}

A final area of continuity between the nineteenth-century North American evangelical revivals and the church in Brazil was the proliferation of a free church model - a contrast to the 'Constantinian' state church which had been prevalent since the fourth-century until the Anabaptist Reform. A number of scholars have argued that a free church mentality was encouraged by the First Great Awakening, and the separation of church and state paradigm was a certain outcome (Spickard \& Cragg 1994:260-270; cf. Ahlstrom 2004:290-294; Hankins 2004:4). Noll remarks that Baptist churches in particular flourished in the southern colonies at this time because there was an alternative to the official Anglican Church (Noll 1992:99-103).

Arguably, each of the evangelical qualities discussed - a high regard for the Scriptures, a call to genuine conversion, a visible faith, a missionary zeal, and the priesthood of the believer - fuelled the notion of a free, believer's church in Europe, in North America, and in Brazil. As noted, those immigrant churches in Brazil which were established prior to the first wave of evangelical missions were either official Lutheran or Anglican state churches, or mainline denominations, with little missionary emphasis. Not surprisingly, conflict was experienced between the immigrant churches and the evangelical missionaries (Gonzalez 2007:204-205). The North American missionaries, entering a Brazilian context, which was politically and culturally fatigued, and functioning in terms of a state church model, planted free churches throughout the country. Some missionaries from official church backgrounds in Europe - such as the Scottish Presbyterian Robert Reid Kalley and some Anglican workers - established churches in Brazil, which were, essentially, much more free church than they were traditional in their thinking. Such an enduring free church value is implicit in a recent article on global missiology by Steuernagel, a Brazilian missiologist from the Lutheran tradition, who advocates 'a season of "local initiative"', in terms of which 'local initiatives replace centralized activities' in global mission efforts (Steuernagel 2000:131)

\section{SUMMARISING BRAZIL'S EVANGELICAL IDENTITY}

Apart from the documented paradigm shift in thinking on missions in Roman Catholic countries and in Latin America, which emerged within the Student Volunteer Movement, the literature related to eighteenth- and nineteenth-century evangelical awakenings is not directly linked to mission work in Brazil. However, a careful assessment of the identity of Brazilian evangelicalism reveals some pietistic influences consisting of, at the very least, a strong correlation with such work - that were at work during the Second Great Awakening in the decades preceding the first evangelical mission efforts to Brazil in the mid-nineteenth century. Accordingly, it has been argued that Brazilian evangelicalism is characterised by a high regard for the Scriptures, a call to genuine conversion, a visible faith, a missionary zeal, the priesthood of the believer, and a free church tendency.

Freston generally places Brazilian evangelicalism within Bebbington's quadrilateral; however, he rightly concludes that the movement is slightly larger than either its European or its North American counterparts. First, Brazilian and Latin American evangelicals, led largely by the Latin American Theological Fraternity, have been committed to delivering the 'whole' Gospel, as well as to ministering to social needs. Although not fully embracing Liberation Theology, such evangelicals have taken seriously the issues raised by liberal Protestants and Catholics in this regard, incorporating them into their missiology (Freston 1994:233-238; cf. Ekström 2009:372).

Secondly, Brazilian evangelicals are generally more ecumenica in their regard for other evangelicals than are North American and European evangelicals, who have, historically, found more reason to be less inclusive (Freston 2004:221). Within the Brazilian and Latin American context, 'evangelical' and 'Protestant' are understood to mean the same thing. Also, with $70 \%$ of the Brazilian evangelicals belonging to Pentecostal churches, the remaining minority of Methodists, Presbyterians, Baptists and other non-Pentecostal denominations clearly chose, in the second half of the twentieth century, to accept Pentecostals as evangelicals. Although such a finding does not mean that there has been an absence of theological reflection, Brazilian evangelicals seem to be generally inclusive of other like-minded Christians: 'theologically conservative, pietistic in spirituality, and very zealous about evangelization' (Escobar 2002:10)

On the basis of such an evangelical identity, the Brazilian church has continued to grow numerically within Brazil. Also, as was earlier noted in the current article, during the past thirty years, the Brazilian evangelical church has developed into a formidable sender of transcultural missionaries to other countries, comprising a movement within the global church which merits ongoing study and observation. 


\section{REFERENCES}

Ahlstrom, S.E., 2004, A religious history of the American people, Yale University Press, New Haven.

Anderson, J., 2005, An evangelical saga: Baptists and their precursors in Latin America, Xulon, Longwood.

Arnold, F.L., 2006, 'A peek in the baggage of Brazil's pioneer missionaries', Missiology: An International Review, 34(2), 125-134.

Bebbington, D., 1989, Evangelicalism in modern Britain: A history from the 1730s to the 1980s, Unwin Hyman, London.

Berg, M. \& Pretiz, P., 1994, 'Five waves of Protestant evangelization', in G. Cook (ed.), New face of the Church in Latin America: Between tradition and change, pp. 56-67, Orbis, Maryknoll.

Bevans, S.B. \& Schroeder, R.P., 2004, Constants in context: A theology of mission for today, Orbis, Maryknoll.

Bonino, J.M., 1995, Faces of Latin American Protestantism, Eerdmans, Grand Rapids.

Bosch, D., 1990, Transforming mission, Orbis, Maryknoll.

Braga, E. \& Grubb, K.G., 1932, The Republic of Brazil: A survey of the religious situation, World Dominion Press, London.

Central Intelligence Agency World Factbook, n.d., Brazil, viewed 27 March 2009, from https://www.cia.gov/library/ publications/the-world-factbook/geos/br.html

Chaney, C.L., 1976, The birth of missions in America, William Carey Library, Pasadena.

Chestnut, R.A., 1997, Born again in Brazil: The Pentecostal boom and the pathogens of poverty, Rutgers University Press, Rutgers.

Comblin, J., 1994, 'Brazil: Base communities in the northeast', in G. Cook (ed.), New face of the Church in Latin America: Between tradition and change, pp. 202-225, Orbis, Maryknoll.

Cook, G., 1994a, 'Introduction: The changing face of the church in Latin America', in G. Cook (ed.), New face of the Church in Latin America: Between tradition and change, pp. ix-xiv, Orbis, Maryknoll.

Cook, G., 1994b, 'The many faces of the Latin American church', in G. Cook (ed.), New face of the Church in Latin America: Between tradition and change, pp. 268-276, Orbis, Maryknoll.

Cook, G., 1994c, 'Protestant mission and evangelization'. in G. Cook (ed.), New face of the Church in Latin America: Between tradition and change, pp. 41-55, Orbis, Maryknoll.

Douglas, J.D. (ed.), 1974, Let the earth hear His voice, International congress on world evangelization, Lausanne, Switzerland, World Wide Publications, Minneapolis.

Ekström, B., 2009, 'Brazilian sending', in R.D. Winter \& S.C. Hawthorne (eds.), Perspectives on the world Christian movement: A reader, 4th edn., pp. 371-372, William Carey Library, Pasadena.

Ekström, B., 1998, 'Uma análise histórica dos objetivos da Associação de Missões Transculturais Brasilerias e o seu Cumprimento' [A historical analysis of the goals of Association of Transcultural Missions Brazil and its Fulfillment], MTh thesis, Faculdade Teológica Batista de São Paulo.

Escobar, S., 1994, 'The church in Latin America after five hundred years: An evangelical missiological perspective', in G. Cook (ed.), New face of the Church in Latin America: Between tradition and change, pp. 21-37, Orbis, Maryknoll.

Escobar, S., 2003, The new global mission: The Gospel from everywhere to everyone, Intervarsity, Downers Grove.

Escobar, S., 2002, Changing tides: Latin America and world mission today, Orbis, Maryknoll.

Freston, P., 1994, 'Brazil: Church growth, parachurch agencies, and politics', in G. Cook (ed.), New face of the Church in Latin America: Between tradition and change, pp. 226-242, Orbis, Maryknoll.
Freston, P., 2004, 'Contours in Latin American Pentecostalism', in D. Lewis (ed.), Christianity reborn: the global expansion of evangelicalism in the twentieth century, pp. 221-270, Eerdmans, Grand Rapids.

George, S.K., 2002, 'Brazil: An "evangelized" giant calling for liberating evangelism', International Bulletin of Missionary Research, July, 104-109.

George, S.K., 2006, 'Presbyterian seeds bear fruit in Brazil as doors to partnership open and close', Missiology: An International Review 34(2), 135-149.

George, T., 2008, 'Evangelical revival and missionary awakening', in M. Klauber \& S. Manetsch (eds.), The Great Commission: Evangelicals and the history of world missions, pp. 44-63, B\&H Academic, Nashville.

Gonzalez, J., 2007, Christianity in Latin America: A history, Cambridge University Press, Cambridge.

Hall, T.D., 2009, 'The Protestant Atlantic awakening and the origins of an evangelical missionary sensibility', paper presented at the Conference on Awakenings and Revivals in American History, Liberty University, Lynchburg, VA, 16 April.

Hankins, B., 2004, The Second Great Awakening and the Transcendentalists, Greenwood Press, Westport.

Haykin, M. \& Stewart K.J. (eds.), 2008, The advent of Evangelicalism: Exploring historical continuities, B\&H Academic, Nashville.

Hoornaert, E., 1992, 'The Church in Brazil', in E. Dussel, (ed.), The Church in Latin America: 1492-1992, pp. 185-200, Orbis, Maryknoll.

Horner, N., 1965, Cross and crucifix in mission, Abingdon Press, Nashville.

Jenkins, P., 2006, The new faces of Christianity: Believing the Bible in the global South, Oxford University Press, Oxford.

Jenkins, P., 2007, The next Christendom: The coming of global Christianity, Oxford University Press, Oxford.

Kane, J. H., 1982, A concise history of the Christian world mission: A panoramic view of missions from Pentecost to the present, Baker Academic, Grand Rapids.

Kidd, T., 2008, 'Prayer for a saving issue', in M. Haykin \& K.J. Stewart (eds.), The advent of Evangelicalism: Exploring historical continuities, pp. 129-145, B\&H Academic, Nashville.

Latourette, K.S.,1937-1945, A history of the expansion of Christianity, vols. 1-7, Harper Brothers, New York.

Mariz, C., 1994, 'Religion and poverty in Brazil', in G. Cook, (ed.), New face of the Church in Latin America: Between tradition and change, pp. 75-81, Orbis, Maryknoll.

Martin, D., 1993, Tongues of fire: The explosion of Protestantism in Latin America, Wiley-Blackwell, Oxford.

Mendonça, A.G., 1996, 'A history of Christianity in Brazil: An interpretive essay', International Review of Mission 85(338), 367-387.

Noll, M.A., 1992, A history of Christianity in the United States and Canada, Eerdmans, Grand Rapids.

Noll, M.A., 2004, 'Evangelical identity, power, and culture in the "great" nineteenth century', in D. Lewis (ed.), Christianity reborn: The global expansion of Evangelicalism in the twentieth century, pp. 31-51, Eerdmans, Grand Rapids.

Noll, M.A., 2009, The new shape of world Christianity: How American experience reflects global faith, Intervarsity, Downers Grove.

Padilla, R., 1994, 'New actors on the political scene', in G. Cook (ed.), New face of the Church in Latin America: Between tradition and change, pp. 82-95, Orbis, Maryknoll.

Parker, M., 1998, The kingdom of character: The student volunteer movement for foreign missions (1886-1926), University Press of America, Lanham.

Penyak, L.M. \& Petry, W.J. (eds.), 2006, Religion in Latin America: A documentary history, Orbis, Maryknoll.

Prado, O. n.d., 'The Brazil model', AD 2000, viewed 29 January 2009, from http://www.ad2000.org/gcowe95/prado.html. 
Prado, O., 2005, 'A new way of sending missionaries: Lessons from Brazil', Missiology: An International Review 33(1), 48-60.

Read, W.R. \& Ineson, F.A., 1973, Brazil 1980: The Protestant handbook, MARC, Monrovia.

Robert, D.L., 2000, 'Shifting southward: Global Christianity since 1945', International Bulletin of Missionary Research 24(2), $50-58$.

Robert, D.L., 1986, 'The origin of the student volunteer watchword: "The evangelization of the world in this generation"', International Bulletin of Missionary Research 10(4), 146-149.

Salinas, J.D., 2008, 'The Great Commission in Latin America', in M.I. Klauber \& S.M. Manetsch, The Great Commission: Evangelicals and the history of world missions, pp. 134-148, B\&H Academic, Nashville.

Saracco, N., 2000, 'Mission and missiology from Latin America', in W. Taylor (ed.), Global missiology for the 21st century: The Iguassa Dialogue, pp. 357-366, Baker Academic, Grand Rapids.

Scott, C., 2009, 'Latin American sending', in R. Winter \& S.C. Hawthorne (eds.), Perspectives on the world Christian movement: A reader, 4th edn., p. 375, William Carey Library, Pasadena.

Sepúlveda, J., 1994, 'The Pentecostal Movement in Latin America', in G. Cook (ed.), New face of the Church in Latin America: Between tradition and change, pp. 68-74, Orbis, Maryknoll.

Smith, A.C., 1983, 'The essentials of missiology from the evangelical perspective of the "Fraternidad Teológica Latinoamerica"', $\mathrm{PhD}$ thesis, The Southern Baptist Theological Seminary.
Speer, R.E., Inman, S.G. \& Sanders, F.K. (eds.), 1925, Christian work in South America: Official report of the Congress on Christian Work in South America at Montevideo, Uruguay, April 1925, vols. 1 \& 2, Revell, New York.

Speer, R.E., 1912, South American problems, Student Volunteer Movement for Volunteer Missions, New York.

Spickard, P.R. \& Cragg, K.M., 1994, A global history of Christians: How everyday believers experienced their world, Baker Academic, Grand Rapids.

Stark, R., 2001, 'Efforts to Christianize Europe, 400-2000', Journal of Contemporary Religion 16(1), 105-123.

Steuernagel, V.R., 2000, 'Learning from Escobar ... and beyond', in W. Taylor (ed.), Global missiology for the 21st century: The Iguassa dialogue, pp. 123-132, Baker Academic, Grand Rapids.

Stoll, D., 1991, Is Latin America turning Protestant? The politics of evangelical growth, University of California, Berkley.

Tucker, H., 1902, The Bible in Brazil: Colporteur experiences, Revell, New York.

Willems, E., 1967, Followers of the New Faith: Culture change and the rise of Protestantism in Brazil and Chile, Vanderbilt University Press, Nashville.

Winfried Every-Clayton, J., 2002, 'The legacy of Robert Reid Kalley', International Bulletin of Missionary Research 26(3), $123-127$. 